\title{
PROCESSOS DE CONSTRUÇÃO TEXTUAL NO DISCURSO (ORAL/ESCRITO) DE ADOLESCENTES DO ENSINOFUNDAMENTAL
}

Karin Gutz

\begin{abstract}
Resumo: Este projeto teve por objetivo estudar os processos de construção textual (repetição e paráfrase) na produção discursiva de jovens adolescentes, do ensino fundamental e médio, observando quais os tipos de processos emipregados, quais as funçōes desempenhadas e se esses. processos são substituidos na modalidade escrita. Palavras-chave: repetição; paráfrase; língua oral; língua escrita; adolescentes.
\end{abstract}

\section{Introdução}

O projeto de estudo das estratégias de construção textual de estudantes do ensino fundamental se iniciou em julho de 1997 , sob a orientação da Prof. ${ }^{a}$ Dr. ${ }^{a}$ Maria Lúcia da Cunha Victório de Oliveira Andrade. Teve por objetivo geral contribuir para o ensino de Língua Portuguesa por meio de um estudo comparativo entre a modalidade oral e escrita, visando ampliar os conhecimentos sobre a produção discursiva de adolescentes e criar bases para planejamentos metodológicos de ensino, tanto de natureza oral como escrita.

Mais especificamente, pretendeu estudar os procedimentos de construção textual (paráfrase e repetição) na produção discursiva de jovens adolescentes de $5^{*}$ e $8^{4}$ série, procurando respostas para as seguintes perguntas:

Quais os tipos de formulação (repetição paráfrase) que estão presentes no discurso oral e escrito de adolescentes?

Bolsista PIBIC-USP/CNPq (julho de 1998 - julho de 2000) Área de Filologia e Língua Portuguesa-FFLCH-USP. 
A oralidade e a escrita compartilham procedimentos que evidenciam as mesmas funções de formulação?

A frequeuência de uso das repetições e paráfrases diminui no discurso escrito? Se diminui, desaparecem as funções ou estas se realizam por meio de outros recursos lingüísticos?

Há distinções entre formas e funções adquiridas pela repetição e paráfrase no discurso dos alunos de $5^{\mathrm{a}}$ série e entre os da $8^{\mathrm{a}}$ série?

Tais perguntas motivaram o trabalho que teve por base um corpus composto por 180 min de gravações e trinta redações. As entrevistas foram realizadas no próprio ambiente escolar (escola particular de São Paulo) para que se criasse uma atmosfera familiar ao aluno. Tais entrevistas foram realizadas durante um mês; nesse mesmo período, foi pedido aos alunos que elaborassem uma redação sobre o mesmo tema narrado.

\section{Metodologia e análise de dados}

As gravações foram transcritas e o modelo de transcrição adotado foi o do projeto NURC. A metodologia utilizada para definição e identificação dos tipos formais e funcionais de repetição teve por base a tese Repetição na língua falada: formas e funções de Marcuschi (1992), com algumas alterações. Como base para análise das paráfrases encontradas nos corpora foram utilizados os trabalhos de Hilgert $(1989,1992,1996)$.

Dentre os fatos verificados mediante a análise dos dados alguns merecem ser mencionados.

O primeiro fato que surpreende é que os totais de ocorrências de repetições referentes ao corpus oral e escrito da $5^{2}$ série são muito similares (224 ocorrências no oral $x 216$ no escrito), o que já contradiz, de certa maneira, o que se esperaria de um corpus escrito, no qual se pressupōe um apagamento das repetiçōes. Já de início se pôde supor que a criança faz uso e necessita da repetiçầo de forma quantitativamente equiparável na oralidade e na escrita.

Outro fato que pôde ser observado é que o segmento mais repetido é o lexical, em ambọs os corpora, mas na oralidade a repetição oracional adquire índices bem superiores aos verificados na escrita. O que nos parece é que na língua oral a. criança não tem tanta percepção de que está repetindo e a ausência de riqueza vocabular, bem como a dificuldade em formular uma mesma idécia por intermédio de estruturas formais diferentes, faz com que repita, mais na oralidade que na escrita, segmentos maiores como as orações.

Quanto às funções desempenhadas pelas repetições no corpus da $5^{\mathrm{a}}$ série, a mais significativa é a coesão. E, nas duas modalidades, a repetição como um recurso para referenciar é a concentradora dos maiores índices, sobretudo na escrita, Das 217 ocorrências na língua escrita, 178 correspondem às funções referenciais. A criança parece desconhecer ou evitar processos de referenciação como, por exemplo, a pronominalização; a substituição por um sinônimo também se torna difícil para o aluno de $5^{a}$ série, se considerarmos a falta de riqueza vocabular deles.

O que também se percebe é que na oralidade a repetição adquire uma riqueza maior de usos. Certas funções de formulação características de um planejamento simultâneo à produção discursiva são apagadas na modalidade escrita, como a correção, a reconstrução de estruturas e as hesitações; são mantidas algumas repetições, que já se constituem como repetições estratégicas

Essas repetiçōes estratégicas, ainda que pouco numerosas, e aparenteś apenas em alguns textos, já indicam um certo domínio da linguagem e percepção de quando essas repetições que são, muitas vezes, erroneamente consideradas vícios de linguagem podem ser utilizadas em prol da argumentatividade do texto e encadeamento de idéias.

Ao comparar os dados verificados no corpus da $5^{\text {a }}$ série aos da $8^{\text {a }}$ série, o que se pôde constatar $\epsilon$ que houve uma redução no número de ocorrências de repetições na escrita e um aumento na oralidade. Com um maior domínio da língua materna, o jovem passa a utilizar com mais frequiência processos de pronominalização, apagamento e até mesmo paráfrases. A noção estilística de que se deve evitar a repetição também parece estar mais presente, o que contribui para a redução do número de ocorrências de repetições.

Quanto às funçōes desempenhadas pela repetição, a distinção mais evidente é que, tanto na modalidade escrita como na oralidade, a repetição com função argumentativa apresenta índices superiores aos que foram obtidos na $5^{2}$ série. Com um maior desembaraço na utilização da língua, o adolescente faz uso da repetição como uma forma de articular o texto argumentativo: contrapondo, reafirmando, e contrastando idéias.

No entanto, a utilização da repetição como uma forma de referenciar continua sendo predominante também no corpus da $8^{a}$ série; é nessa função que se encontram os maiores índices nos dois corpora (oral e escrito). Tal fato mereceria 
um estudo mais aprofundado, que eliminasse muitas das variantes que fizeram parte deste trabalho inicial e que se detivesse a observar mais especificamente como se dão as formas de co-referenciação no discurso de adolescentes; verificando porque a repetição adquire um uso tão essencial no ato de referir. A esse estudo pretendo me dedicar na pós-graduação, com um projeto mais enxuto e com mais tempo hábil para ser desenvolvido.

No decorrer deste trabalho, acabou sendo dada maior ênfase à repetição do que à paráfrase, isso porque a repetição possui índices quantitativamente mais expressivos que a paráfrase no discurso adolescente. Deste modo, só puderam ser apontadas algumas tendências gerais das formas e funções adquiridas pela paráfrase.

Em linhas gerais, o que pôde ser notado é que não há modificações muito significativas nas formas e funções desempenhadas pelas paráfrases nos dois corpora $\left(5^{a}\right.$ e $\left.8^{a}\right)$. Um fato interessante é que a escrita dos alunos da $5^{\mathrm{a}}$. série parece compartilhar usos de paráfrase encontrados, basicamente, no corpus oral de falantes de nível de escolaridade mais avançada. Ou seja, a interferência da oralidade no discurso escrito dos alunos da primeira faixa etária se reproduz nos índices referentes à paráfrase. Tal afirmaçăo diz respeito principalmente à paráfrase paralela, que já possui valores pouco significativos no corpus escrito da $8^{a}$ série. $O$ que pode sugerir que a paráfrase paralela talvez seja uma marca do planejamento simultâneo à produção discursiva, no qual a falta de tempo disponível para elaboração de uma idéia faz com que a tentativa de condensá-la ou mesmo expandi-la seja frustrada, resultando em uma paráfrase paralela. Isso poderia justificar os altos índices que a paráfrase paralela adquire na oralidade e não mais na escrita.

Já a criança de $5^{a}$ série, devido às limitações de maturidade intelectual, vocabulário e desembaraço com a modalidade escrita, apesar de dispor de mais tempo para elaboração de um texto escrito, continua fazendo grande uso da paráfrase paralela, que possui índices igualmente altos na escrita.

\section{Considerações finais}

Este projeto serviu para apresentar um panorama geral dos usos de repetição e paráfrase na prođução discursiva de adolescentes de $5^{a}$ e $8^{a}$ série. Infelizmente, o tempo disponível para a realização deste trabalho não permitiu a elaboração de um estudo mais aprofundado, com o recolhimento de um corpus mais amplo, que abarcasse possivelmente a $1^{2}, 5^{a}, 8^{a}$ séries do ensino fundamental e $3^{\mathrm{a}}$ série do ensino médio em escolas particulares e públicas. De qualquer maneira , o corpus permitiu a verificação de algumas dificuldades dos alunos, principalmente no que se refere à 5 a série, o que faz com que seja interessante utilizar o material recolhido para criar bases para planejamentos metodológicos de ensino, tanto de natureza oral como escrita; permitindo também a elaboração de material didático que pudesse ser utilizado em sala de aula; não restringindo, portanto, este estudo ao âmbito teórico, mas utilizando-o para fins práticos.

Abstract: This paper presentes a comparative analyses on the repetition and paraphrase on the teenagers oral and written speech. It aims to show what kinds of process they use, the function these process have and if they are substitute on the written speech.

Keywords: repetition; paraphrase; oral speech; written speech; teenagers. 